\section{Harvest Date Affects Yield and Postharvest Quality of Nondried, Short-day Onions}

\author{
Steven A. Sargent ${ }^{1}$ \\ Horticultural Sciences Department, P.O. Box 110690, University of Florida, \\ Institute of Food and Agricultural Sciences, Gainesville, FL 32611-0690
}

Peter J. Stoffella

Indian River Research and Education Center, University of Florida, Institute of Food and Agricultural Sciences, 2199 South Rock Road, Fort Pierce, FL 34954

\author{
Donald N. Maynard \\ Gulf Coast Research and Education Center, University of Florida, Institute \\ of Food and Agricultural Sciences, Bradenton, FL 34203
}

Additional index words. harvest maturity, sprouting, decay, Allium cepa

\begin{abstract}
Short-day onions (Allium cepa L.) grown under humid, subtropical conditions at two locations were evaluated for bulb size and yield at five harvest dates (H1 to H5) ranging from 94 to 132 days after transplanting (DAT) for 'Granex 33' and from 115 to 153 DAT for 'Texas Grano 1015Y'. Maximum yields were attained by $\mathrm{H} 4$ for both cultivars and were attributed to increased bulb size rather than differences in plant (bulb) population. Nondried, large bulbs $(>7.6 \mathrm{~cm}$ diameter) from each harvest were trimmed and stored at 1 or $10{ }^{\circ} \mathrm{C}$ and $80 \%$ relative humidity (RH) for 2 weeks plus 2 weeks at $20{ }^{\circ} \mathrm{C}$ and $80 \% \mathrm{RH}$ to simulate commercial storage and handling. Initial respiration rates of bulbs of both cultivars decreased $>60 \%$ between $\mathrm{H1}$ and $\mathrm{H} 4$. Bulbs also retained higher fresh weight during storage as harvest was delayed. Storage for 2 weeks at $1{ }^{\circ} \mathrm{C}$ suppressed sprouting of immature (H1) 'Texas Grano 1015Y' bulbs, but not of 'Granex 33' bulbs from one location. Storage at $10{ }^{\circ} \mathrm{C}$ did not suppress sprouting of either cultivar. Decay became more prevalent with delayed harvest, but ' $G$ ranex 33 ' was more resistant to decay than was 'Texas Grano 1015Y', which developed up to $40 \%$ decay after 2 weeks at $20{ }^{\circ} \mathrm{C}$. Harvest at 115 and 132 DAT resulted in acceptable yields for 'Granex 33' and 'Texas Grano 1015', respectively, and satisfactory postharvest quality of nondried bulbs following 2 weeks of storage at $1^{\circ} \mathrm{C}$ and $80 \% \mathrm{RH}$ plus 2 weeks at $20^{\circ} \mathrm{C}$.
\end{abstract}

Onion growth, yield, and bulb quality are significantly affected by environmental factors, including temperature, photoperiod, and soil characteristics, and by cultural practices such as plant population, planting arrangement, fertilization, and irrigation (Brewster, 1977a). Mildly pungent, short-day onions bring higher returns than do the more pungent types, and the former are often marketed as gourmet items. A well-coordinated research and marketing program helped Georgia growers significantly increase production and sales of high-quality "sweet" Vidalia onions (Barton, 1992). However, production of these types in humid, subtropical regions has been quite limited, despite reported potential for

Received for publication 7 Sept. 1999. Accepted for publication 10 May 2000. Florida Agricultural Experiment Station Journal series No. R-06962. We gratefully acknowledge the technical assistance of Judith Zoellner. The cost of publishing this paper was defrayed in part by the payment of page charges. Under postal regulations, this paper therefore must be hereby marked advertisement solely to indicate this fact.

${ }^{1}$ To whom requests for reprints should be addressed. E-mail address: sasa@ufl.edu good yields and quality (Hayslip et al., 1987). Weather is a serious constraint to increased production in these areas because frequent and heavy rains during the growing season favor weed growth, high insect populations, and bulb decay, but delaying fall planting of short-day onions from early September to early October in Texas resulted in a linear decrease in total bulb yields $\left(\mathrm{t} \cdot \mathrm{ha}^{-1}\right)$ (Richwine, 1990). Lower yields have also been reported for onions harvested at earlier dates (Rickard and Wickens, 1977; Stoffella and Sonoda, 1982).

Another limitation to increased production of mildly pungent onions in humid areas is their relatively short postharvest life compared with the more pungent types. Harvest maturity affects postharvest life (Tucker and Drew, 1982) and carbohydrate content (Nilsson, 1980) of onion bulbs. Smittle and Maw (1988) harvested and dried two mild onion cultivars ('Granex 33', 'Sweet Georgia') at typical harvest maturity. Postharvest losses for bulbs from the first harvest were minimal during 1 month of storage at 22 to 25 ${ }^{\circ} \mathrm{C}$. However, the percentage of marketable bulbs after storage decreased when bulbs were harvested later. Wall and Corgan (1994) obtained similar results with dried, short-day onions; as harvest was delayed, the incidence of decay increased during $20 \mathrm{~d}$ of storage under ambient conditions. Kopsell and Randle (1997) found that short-day onions, when dried for $7 \mathrm{~d}$ under cover at 20 to $25^{\circ} \mathrm{C}$, sprouted after $\approx 2$ months of storage at $5{ }^{\circ} \mathrm{C}$, whereas more pungent, long-day cultivars remained dormant during storage for up to 8 months. Note that "drying" is the most accurate term for onions, since moisture is removed from the neck and outer scales of the bulb, serving as protective barriers during subsequent handling and storage. "Curing" is appropriate for crops such as potatoes (Solanum tuberosum L.) that undergo suberization in response to mechanical injuries.

Harvested bulbs are particularly susceptible to soft-rot bacteria (notably, Erwinia sp. and Pseudomonas sp.) and fungal species that infect the neck region and cuts (Snowden, 1992). Several postharvest handling methods have proven effective in reducing storage decay, including field and artificial drying (removal of $3 \%$ to $5 \%$ moisture) (Hoyle, 1948), drying in conjunction with refrigerated storage at $0{ }^{\circ} \mathrm{C}$ and $65 \%$ to $70 \%$ relative humidity (RH) (Hardenburg et al., 1986), application of maleic hydrazide prior to harvest and top rolling (Toledo et al., 1984), and controlled atmosphere storage (Isenberg, 1979). Short-day onions grown under subtropical conditions stored best when harvested at $10 \%$ to $20 \%$ fallen tops, followed by trimming of the tops to 2.5 to $5.0 \mathrm{~cm}$ prior to packing (Hayslip et al., 1978).

Field drying is considered unreliable in subtropical production areas because of the unpredictability of rains. The extra costs associated with purchase of drying equipment have discouraged many vegetable growers from growing short-day onions. However, many growers have access to refrigerated storage used to store other crops. If refrigerated storage of nondried, short-day onions provided sufficient postharvest life for commercial marketing, more vegetable growers could plant these high-value onion types.

In this study, two short-day onion cultivars were grown under humid, subtropical conditions at two locations. Bulb size and quality and yields were determined as a function of five harvest dates, and postharvest quality of nondried bulbs was studied during subsequent refrigerated storage.

\section{Materials and Methods}

Cultural practices. Experiments were conducted at two locations in southern Florida with similar conditions: the Indian River Research and Education Center at Fort Pierce (Atlantic Ocean coast) and the Gulf Coast Research and Education Center at Bradenton (Gulf of Mexico coast). Soils were characterized as an Oldsmar fine sand (sandy, siliceous, hyperthermic, Alfic Arenic Haplaquods) at Fort Pierce and an EauGalle fine sand (sandy, siliceous, hyperthermic Aeric Haplaquods) at Bradenton. 
Raised beds were constructed at both locations $(0.15 \mathrm{~m}$ high $\times 1.1 \mathrm{~m}$ wide and 2.1 $\mathrm{m}$ apart at Fort Pierce, and $0.20 \mathrm{~m}$ high $\times 1.3$ $\mathrm{m}$ wide and $1.5 \mathrm{~m}$ apart at Bradenton). Fertilizer was broadcast and soil-incorporated into the beds. At the Fort Pierce site, fertilizer $\left(192 \mathrm{~N}-70 \mathrm{P}-138 \mathrm{~K} \mathrm{~kg} \cdot \mathrm{ha}^{-1}\right)$ was initially applied; following heavy rainfall $(25.4 \mathrm{~cm})$ in January and February, an additional application $\left(83 \mathrm{~N}-13 \mathrm{P}-36 \mathrm{~K} \mathrm{~kg} \cdot \mathrm{ha}^{-1}\right)$ was broadcast onto the beds. At the Bradenton site, a single application $\left(269 \mathrm{~N}-98 \mathrm{P}-192 \mathrm{~K} \mathrm{~kg} \cdot \mathrm{ha}^{-1}\right)$ was applied. Subsurface irrigation was used in both experiments. Pesticides were applied as needed to control insects, diseases, and weeds during production.

'Texas Grano 1015Y' and 'Granex 33' onion seedlings (7-week-old, Speedling ${ }^{\circledR}$ 080A plants) were transplanted in early December at both locations using a randomized complete-block design, with five treatments (harvest dates) replicated four times, for a total of 20 plots. Each plot was $3 \mathrm{~m}$ in length and contained three rows spaced $20 \mathrm{~cm}$ apart; transplants were spaced $10 \mathrm{~cm}$ apart within each row (total of 90 transplants/plot). Plant populations were equivalent to 56,007 and 78,408 plants/ha at the Fort Pierce and Bradenton sites, respectively.

Harvest dates. Treatments consisted of five harvest dates. 'Granex 33' is an early maturing cultivar (Hayslip et al., 1987); therefore the initial harvest was earlier than for 'Texas Grano 1015Y'. Harvest maturity can be approximated using the number of days from transplanting for the cultivar. Harvest dates were $94,104,115,124$, and 132 d after transplanting (DAT) for 'Granex 33' and $115,124,132,144$, and 153 DAT for 'Texas Grano 1015Y'. At the first harvest of each cultivar, shoot tips had senesced but $<5 \%$ of the tops had fallen, whereas at the last harvest, nearly all tops had senesced and fallen.

Bulb size and yield measurements. A 2.4$\mathrm{m}$ section of each plot was harvested on each assigned harvest date. Bulbs were graded as marketable or culls (misshapen, splits, doubles, etc.), counted, and weighed. Marketable bulbs were sized by equatorial diameter into small $(<5 \mathrm{~cm})$, medium (5.0 to 7.6 $\mathrm{cm})$, and large $(>7.6 \mathrm{~cm})$ categories and weighed. Weights of the marketable categories were converted to percentage of total yield.

Postharvest treatments and measurements. For each location, cultivar, harvest date, and replicate (plot), the largest 15 bulbs (average $=330 \mathrm{~g} / \mathrm{bulb}$ ) were bagged and, within $24 \mathrm{~h}$ of harvest, transported at ambient temperature to Gainesville, Fla. Within $6 \mathrm{~h}$ of arrival, the bulbs were brushed to remove any adhering soil, stems were trimmed to $2.5 \mathrm{~cm}$ and roots were removed. The 15 bulbs from each plot were randomly distributed as follows: five bulbs each for storage quality determinations at 1 or $10{ }^{\circ} \mathrm{C}$ and $75 \%$ to $85 \%$ $\mathrm{RH}$, two bulbs for determination of initial firmness, and three bulbs for determination of respiration rate during storage. Initial quality analyses were performed (see below), and the 10 bulbs for future evaluations were placed in netted bags (five/bag) for 2 weeks of storage followed by transfer to $20{ }^{\circ} \mathrm{C}$ for an additional 2 weeks.

Firmness, fresh weight, and respiration rate were determined initially, after 2 weeks of storage at 1 and $10^{\circ} \mathrm{C}$ (Week 2$)$, and during subsequent storage at $20^{\circ} \mathrm{C}$ (Weeks 3 and 4 ). Firmness was measured nondestructively using a modified version of the Cornell firmness tester (Gull et al., 1980). In this method, a static load of $9.8 \mathrm{~N}$ was applied for $5 \mathrm{~s}$ with a $15-\mathrm{mm}$ convex probe at two locations on the equator of each bulb, and the deformation was measured in millimeters and averaged. Fresh weight was determined per bag of five bulbs. Throughout storage, individual bulbs were also inspected for incidence and severity of decay. At the end of the storage period, percentage of moisture content of each bulb was determined by weight difference after sliced quarters were dried at $\approx 50{ }^{\circ} \mathrm{C}$ for $48 \mathrm{~h}$.

Respiration rates were determined by individually weighing bulbs and placing one bulb in each of three open-top jars $(\approx 3.8 \mathrm{~L})$ at $20{ }^{\circ} \mathrm{C}$. After an initial $24 \mathrm{~h}$ equilibration period, the jars were sealed for $1 \mathrm{~h}$, and two samples $(0.5 \mathrm{~mL}$ each) were withdrawn from the headspace for $\mathrm{CO}_{2}$ analysis by gas chromatography (Fisher model 1200 Gas Partitioner; Fisher Scientific, Pittsburgh). The data were converted to $\mathrm{mg} \mathrm{CO}_{2} \cdot \mathrm{kg}^{-1} \cdot \mathrm{h}^{-1}$. Means for the three bulbs/plot were analyzed statistically.

Statistical analyses: Since each variety was harvested at different DAT, bulb size and yield data were subjected to analysis of variance (ANOVA) by variety for each location (SAS Institute, 1985). Percentage data were transformed to square root-arcsin prior to ANOVA. The main effects of harvest dates were partitioned into linear, quadratic, or cubic contrasts. The storage experiments were analyzed using a split-plot experimental design. Quality data for each field plot were averaged, with storage temperature as the main plot and harvest time as the subplot for each cultivar and location, and analyzed using ANOVA.

Table 1. Onion yields as influenced by cultivar and harvest maturity.

\begin{tabular}{|c|c|c|c|c|c|c|c|c|c|c|}
\hline \multirow[b]{3}{*}{ Harvest } & \multicolumn{5}{|c|}{ Granex 33} & \multicolumn{5}{|c|}{ Texas Grano 1015Y } \\
\hline & \multirow[b]{2}{*}{ DAT $^{2}$} & \multicolumn{3}{|c|}{ Marketable yield } & \multirow{2}{*}{$\begin{array}{c}\text { Culls } \\
(\%)\end{array}$} & \multirow[b]{2}{*}{ DAT } & \multicolumn{3}{|c|}{ Marketable yield } & \multirow{2}{*}{$\begin{array}{r}\text { Culls } \\
(\%)\end{array}$} \\
\hline & & t.ha $a^{-1}$ & No. bulbs ${ }^{y}$ & $\mathrm{~g} / \mathrm{bulb}$ & & & $\overline{t \cdot h a^{-1}}$ & No. bulbs ${ }^{y}$ & $\mathrm{~g} / \mathrm{bulb}$ & \\
\hline \multicolumn{11}{|c|}{ Bradenton } \\
\hline 1 & 94 & 24.6 & 174 & 143 & 0.0 & 115 & 19.1 & 171 & 112 & 0.0 \\
\hline 2 & 104 & 35.6 & 173 & 206 & 0.9 & 124 & 31.9 & 166 & 192 & 1.2 \\
\hline 3 & 115 & 42.8 & 167 & 255 & 2.1 & 132 & 39.7 & 176 & 227 & 2.6 \\
\hline 4 & 124 & 45.0 & 164 & 273 & 6.3 & 144 & 43.1 & 180 & 240 & 2.7 \\
\hline 5 & 132 & 41.9 & 147 & 285 & 8.7 & 153 & 41.8 & 167 & 247 & 3.4 \\
\hline Significa & $\operatorname{cec}^{\mathrm{x}}$ & $\mathrm{Q}^{* *}$ & $\mathrm{~L}^{*}$ & $\mathrm{Q}^{* *}$ & $\mathrm{~L}^{* *}$ & & $\mathrm{Q}^{* *}$ & NS & $\mathrm{Q}^{* *}$ & NS \\
\hline \multicolumn{11}{|c|}{ Ft. Pierce } \\
\hline 1 & 94 & 16.3 & 136 & 121 & 0.2 & 115 & 13.2 & 128 & 103 & 5.5 \\
\hline 2 & 104 & 22.9 & 135 & 170 & 0.7 & 124 & 18.8 & 130 & 145 & 7.4 \\
\hline 3 & 115 & 24.4 & 131 & 187 & 7.9 & 132 & 28.6 & 135 & 212 & 2.1 \\
\hline 4 & 124 & 32.3 & 130 & 248 & 6.4 & 144 & 34.1 & 128 & 266 & 10.1 \\
\hline 5 & 132 & 31.1 & 130 & 239 & 5.5 & 153 & 34.2 & 121 & 282 & 13.2 \\
\hline \multicolumn{2}{|c|}{ Significance } & $\mathrm{L}^{* *}$ & NS & $\mathrm{L}^{* *}$ & $\mathrm{~L}^{*}$ & & $\mathrm{~L}^{* *}$ & $\mathrm{Q}^{* *}$ & $\mathrm{~L}^{* *}$ & $\mathrm{~L}^{*}$ \\
\hline
\end{tabular}

${ }^{2}$ Days after transplant.

yThousand bulbs/ha.

${ }^{\mathrm{x}}$ Linear $(\mathrm{L})$ or quadratic $(\mathrm{Q})$.

Ns, ****Nonsignificant or significant at $P \leq 0.05$ or 0.01 .
Bulb size and yield response. Bulbs grown at both locations were quite small at Harvest 1 (H1) and $\mathrm{H} 2$, and, in some cases, H3 (Table 1). Although transplanted on the same date, both cultivars from Bradenton were somewhat more mature at the five harvests than those from Ft. Pierce. Differences in growing conditions between locations, possibly because of nutrient leaching during a torrential rainfall at the Ft. Pierce site, may have delayed maturity. Percentage of top fall at $\mathrm{H} 1$ to $\mathrm{H} 5$ at Bradenton was about $0 \%, 5 \%, 20 \%$, $50 \%$, and $100 \%$, respectively, for 'Granex 33 ', whereas that for 'Texas Grano $1015 \mathrm{Y}$ ' was somewhat delayed, at about $0 \%, 0 \%, 5 \%$, $25 \%$, and $50 \%$ for the same respective harvests (data not shown). Percentage of top fall was generally less for both cultivars at Ft. Pierce.

Marketable bulb yields of 'Granex 33' and 'Texas Grano 1015Y' increased linearly or quadratically at each location as each harvest was delayed (Table 1). Stoffella and Sonoda (1982), Rickard and Wickens (1977), and Wall and Corgan (1994) all reported that delaying harvest increased onion yields. The increased marketable yields (Table 1) at the later harvests were attributed to a greater percentage of large bulbs (Table 2) for both cultivars at both sites.

Although bulb size generally increased with each successive harvest, the proportion of culls (percentage of total bulb weight) increased linearly for 'Granex 33' at both locations and for 'Texas Grano 1015Y' at the Ft. Pierce location (Table 1), with physiological disorders (splits, seconds, or misshapen bulbs) being the primary cause. Mean bulb weight increased linearly or quadratically with successive harvest dates for both cultivars at both locations (Table 1).

Harvest maturity and postharvest quality. Bulb maturity at harvest significantly affected several postharvest quality variables for both cultivars. The respiration rate at harvest was highest at $\mathrm{H} 1$, followed by a dramatic reduc- 
Table 2. Onion bulb diameter (\% distribution) as influenced by cultivar and harvest maturity.

\begin{tabular}{|c|c|c|c|c|c|c|c|c|}
\hline \multirow[b]{2}{*}{ Harvest } & \multicolumn{4}{|c|}{ Granex 33} & \multicolumn{4}{|c|}{ Texas Grano 1015Y } \\
\hline & $\mathrm{DAT}^{\mathrm{z}}$ & Small $^{y}$ & Medium & Large & DAT & Small & Medium & Large \\
\hline \multicolumn{9}{|c|}{ Bradenton } \\
\hline 1 & 94 & 27.1 & 44.0 & 28.9 & 115 & 51.4 & 32.2 & 16.3 \\
\hline 2 & 104 & 22.5 & 19.5 & 58.0 & 126 & 30.8 & 26.4 & 42.8 \\
\hline 3 & 115 & 18.0 & 7.6 & 74.4 & 132 & 19.5 & 28.2 & 52.3 \\
\hline 4 & 124 & 19.6 & 12.1 & 68.3 & 144 & 23.7 & 34.5 & 41.7 \\
\hline 5 & 132 & 18.6 & 7.2 & 74.2 & 153 & 13.1 & 25.6 & 61.3 \\
\hline Significance $^{x}$ & & NS & $\mathrm{C}^{*}$ & $\mathrm{Q}^{* *}$ & & $\mathrm{C}^{*}$ & $\mathrm{C}^{*}$ & $\mathrm{C}^{* * *}$ \\
\hline \multicolumn{9}{|c|}{ Ft. Pierce } \\
\hline 1 & 94 & 32.6 & 52.2 & 15.2 & 115 & 58.7 & 35.3 & 6.0 \\
\hline 2 & 104 & 16.9 & 38.3 & 44.8 & 124 & 28.3 & 56.7 & 15.0 \\
\hline 3 & 115 & 8.8 & 37.8 & 53.4 & 132 & 12.0 & 47.8 & 40.2 \\
\hline 4 & 124 & 3.7 & 18.1 & 78.8 & 144 & 4.8 & 31.4 & 63.8 \\
\hline 5 & 132 & 2.2 & 20.6 & 77.1 & 153 & 2.3 & 34.4 & 63.3 \\
\hline Significance & & $\mathrm{L}^{* *}$ & $\mathrm{~L}^{* *}$ & $\mathrm{~L}^{* *}$ & & $\mathrm{Q}^{* * *}$ & $\mathrm{C}^{* *}$ & $\mathrm{C}^{*}$ \\
\hline
\end{tabular}

${ }^{2}$ Days after transplant.

${ }^{y}$ Size categories: Small $(<5 \mathrm{~cm})$, Medium $(5-7.6 \mathrm{~cm})$, and Large $(>7.6 \mathrm{~cm})$.

${ }^{x}$ Linear (L), quadratic (Q), cubic (C).

Ns, *,**Nonsignificant or significant at $P \leq 0.05$ or 0.01 .



Fig. 1. Initial respiration rates for onion bulbs harvested at five maturities ('Granex 33': 94, 104, 115, 124, and $132 \mathrm{~d}$ after transplant; 'Texas Grano 1015Y': 115, 124, 132, 144, and $153 \mathrm{~d}$ after transplant) from two locations. $(n=4)$.

tion at subsequent harvests for both cultivars at both sites ( 24 to $32 \mathrm{mg} \cdot \mathrm{kg}^{-1} \cdot \mathrm{h}^{-1}$ of $\mathrm{CO}_{2}$ ) (Fig. 1). The higher respiration rates at $\mathrm{H} 1$ and $\mathrm{H} 2$ at both sites indicated that the bulbs were still quite immature and actively growing, whereas the lower respiration rates for bulbs harvested later indicate that the bulbs had reached maturity, as reported by Hardenburg et al. (1986) for dried onions.

Bulbs of both cultivars from $\mathrm{H} 1$ generally sprouted more during storage than those from subsequent harvests, whereas virtually no sprouting was evident in H5 bulbs (Table 3). Storage for 2 weeks at $1{ }^{\circ} \mathrm{C}$ suppressed sprouting of 'Texas Grano 1015Y' bulbs from H1 at Bradenton; however, after 1 additional week at $20{ }^{\circ} \mathrm{C}$, sprouting was similar to that of onions stored initially at $10^{\circ} \mathrm{C}$ for both locations (Table 3). 'Granex 33' from the Bradenton location had $<1 \%$ sprouting when stored at either temperature; however, those averaged $0.1 \mathrm{~cm}$ and $6.6 \mathrm{~cm}$, respectively (data not shown). Sprouts for bulbs from $\mathrm{H} 2$ grew significantly less during storage, and by $\mathrm{H} 3$, the bulbs did not sprout during the extended storage period, indicating that they were dormant.

The occurrence of storage decay was cultivar-related and attributed primarily to bacterial soft rot. There was no appreciable decay in 'Granex 33' after 4 weeks of storage, irrespective of harvest maturity, location or storage temperature (data not shown). 'Texas Grano 1015Y' from Bradenton had no decay after 2 weeks storage at either 1 or $10{ }^{\circ} \mathrm{C}$, although following 2 additional weeks at $20{ }^{\circ} \mathrm{C}, 12.5 \%(\mathrm{H} 4)$, and $5 \%(\mathrm{H} 5)$ of the bulbs were severely decayed (lesions extending from the cut stem into the bulb). Bulbs from $\mathrm{H} 5$ (Ft. Pierce) stored at $1{ }^{\circ} \mathrm{C}$ for 2 weeks had less decay than those stored at $10{ }^{\circ} \mathrm{C}(15 \%$ and $30 \%$ mild decay ratings, respectively, where mild decay consisted of apparent, but superficial lesions). However, following 2 weeks of storage at $20^{\circ} \mathrm{C}$, the severity rating for bulbs stored at these respective temperatures increased to $40 \%$ and $30 \%$ severe decay.

Drying reduces the potential for bulb infection by decay pathogens during postharvest handling and storage. In this study, decay occurred at moist, cut stems or sites of mechanical injury. Lesions given a slight decay rating following 2 weeks of storage under refrigerated conditions actually dried and became quiescent during subsequent storage for 2 weeks at $20{ }^{\circ} \mathrm{C}$. The storage decay prevalent in 'Texas Grano 1015Y' bulbs from H4 and H5 may have resulted from latent infection from the field at these later harvests. Smittle and Maw (1988) reported that the incidence of storage decay for 'Granex $33^{\prime}$ increased as harvest maturity increased, which they attributed to mechanical injury during commercial harvest. In that study, storage decay was lowest at the early harvest stage when the necks were soft and the crop had $<6 \%$ fallen tops. Wall and Corgan (1994) also reported increased storage decay as harvest was delayed. Morphology also may have been a factor in resistance or susceptibility to decay. 'Texas Grano 1015Y' had a noticeably thicker stem than did 'Granex 33', resulting in a larger wound after the tops were trimmed.

For onions from $\mathrm{H} 1$ to $\mathrm{H} 5$, moisture content (MC) after storage for 2 weeks at 1 or $10{ }^{\circ} \mathrm{C}$ plus 2 weeks at $20^{\circ} \mathrm{C}$ ranged from $92.0 \%$ to $93.5 \%$, respectively (data not shown). There were no trends for cultivar or location. Smittle and Maw (1988) reported that dried 'Granex 33 ' stored for 4 weeks at 25 to $28{ }^{\circ} \mathrm{C}$ had similar $\mathrm{MC}$, ranging from $93.8 \%$ to $94.9 \%$. Bulb firmness was determined throughout storage; however, onions from all treatments remained very firm, with average deformations of only 1.0 and $1.3 \mathrm{~mm}$, respectively, for 'Granex 33' and 'Texas Grano 1015' after 4 weeks of storage (data not shown).

Cumulative weight loss for both cultivars declined as harvest date for both cultivars was delayed. Bulbs from $\mathrm{H} 1 \mathrm{had}$ the greatest weight loss following 2 weeks of storage at either 1 or 
Table 3. Percentage of incidence of sprouting during storage of onion bulbs as influenced by cultivar and harvest maturity.

\begin{tabular}{|c|c|c|c|c|c|c|c|}
\hline \multirow[b]{2}{*}{ Variable } & & \multicolumn{3}{|c|}{$\begin{array}{c}\text { Bradenton } \\
\text { Storage time }(\text { weeks) }\end{array}$} & \multicolumn{3}{|c|}{$\begin{array}{c}\text { Ft. Pierce } \\
\text { Storage time (weeks) }\end{array}$} \\
\hline & & 2 & 3 & 4 & 2 & 3 & 4 \\
\hline \multicolumn{8}{|c|}{ Texas Grano $1015 Y$} \\
\hline Harvest & $\mathrm{DAT}^{\mathrm{y}}$ & & & & & & \\
\hline 1 & 115 & 20.0 & 35.0 & 35.0 & 35.0 & 65.0 & 65.0 \\
\hline 2 & 124 & 5.0 & 7.5 & 7.5 & 10.0 & 22.5 & 22.5 \\
\hline 3 & 132 & 0.0 & 2.5 & 2.5 & 0.0 & 2.5 & 2.5 \\
\hline 4 & 144 & 0.0 & 5.0 & 5.0 & 0.0 & 0.0 & 0.0 \\
\hline 5 & 153 & 0.0 & 0.0 & 0.0 & 0.0 & 0.0 & 5.0 \\
\hline Signifi & $\mathrm{ce}^{\mathrm{x}}$ & ** & $* *$ & $* *$ & $* *$ & $* *$ & $* *$ \\
\hline \multicolumn{8}{|c|}{ Initial storage temperature $\left({ }^{\circ} \mathrm{C}\right)$} \\
\hline 1 & & 0.0 & 9.0 & 9.0 & 0.0 & 17.0 & 17.0 \\
\hline 10 & & 10.0 & 11.0 & 11.0 & 18.0 & 19.0 & 21.0 \\
\hline Signifi & & *** & NS & NS & $* *$ & NS & NS \\
\hline \multicolumn{8}{|c|}{ Harvest $\times$ temperature } \\
\hline Signifi & & $* *$ & NS & NS & $* *$ & NS & NS \\
\hline \multicolumn{8}{|c|}{ Granex 33} \\
\hline Harvest & $\mathrm{DAT}^{\mathrm{y}}$ & & & & & & \\
\hline 1 & 94 & 2.5 & 2.5 & 2.5 & 72.5 & 72.5 & 72.5 \\
\hline 2 & 104 & 0.0 & 2.5 & 2.5 & 0.0 & 5.0 & 7.5 \\
\hline 3 & 115 & 0.0 & 0.0 & 0.0 & 2.5 & 2.5 & 2.5 \\
\hline 4 & 124 & 0.0 & 0.0 & 0.0 & 0.0 & 0.0 & 2.5 \\
\hline 5 & 132 & 0.0 & 0.0 & 0.0 & 0.0 & 0.0 & 2.5 \\
\hline Signifi & & NS & NS & NS & $* *$ & $* *$ & $* *$ \\
\hline \multicolumn{8}{|c|}{ Initial storage temperature $\left({ }^{\circ} \mathrm{C}\right)$} \\
\hline 1 & & 1.0 & 1.0 & 1.0 & 12.0 & 12.0 & 14.0 \\
\hline 10 & & 0.0 & 1.0 & 1.0 & 18.0 & 20.0 & 21.0 \\
\hline Signifi & & NS & NS & NS & $* *$ & $*$ & NS \\
\hline \multicolumn{8}{|c|}{ Harvest $\times$ temperature } \\
\hline Signifi & & NS & NS & NS & $* *$ & NS & NS \\
\hline
\end{tabular}

Table 4. Cumulative weight loss $(\%)$ during storage of onion bulbs at five harvest maturities.

\begin{tabular}{|c|c|c|c|c|c|c|c|}
\hline \multirow[b]{2}{*}{ Variable } & & \multicolumn{3}{|c|}{$\begin{array}{c}\text { Bradenton } \\
\text { Storage time (weeks) } \\
\end{array}$} & \multicolumn{3}{|c|}{$\begin{array}{c}\text { Ft. Pierce } \\
\text { Storage time (weeks) }\end{array}$} \\
\hline & & 2 & 3 & 4 & 2 & 3 & 4 \\
\hline \multicolumn{8}{|c|}{ Texas Grano $1015 Y$} \\
\hline Harvest & DAT $^{y}$ & & & & & & \\
\hline 1 & 115 & 2.6 & 5.0 & 6.1 & 4.2 & 8.3 & 10.3 \\
\hline 2 & 124 & 1.6 & 1.6 & 4.4 & 2.4 & 5.0 & 6.0 \\
\hline 3 & 132 & 1.5 & 1.5 & 3.9 & 2.2 & 4.1 & 5.2 \\
\hline 4 & 144 & 0.5 & 0.5 & 3.0 & 1.5 & 3.5 & 4.6 \\
\hline 5 & 153 & 1.2 & 1.2 & 4.2 & 2.4 & 4.3 & 5.5 \\
\hline Signifi & $\mathrm{ce}^{\mathrm{x}}$ & $* *$ & $* *$ & $* *$ & $* *$ & $* *$ & $* *$ \\
\hline \multicolumn{8}{|c|}{ Initial storage temperature $\left({ }^{\circ} \mathrm{C}\right)$} \\
\hline 1 & & 1.4 & 3.5 & 4.5 & 2.4 & 5.2 & 6.6 \\
\hline 10 & & 1.5 & 3.2 & 4.1 & 2.7 & 5.0 & 6.1 \\
\hline Signifi & & NS & NS & $*$ & $*$ & $*$ & $*$ \\
\hline \multicolumn{8}{|c|}{ Harvest $\times$ temperature } \\
\hline Signifi & & NS & NS & $*$ & $*$ & NS & $*$ \\
\hline \multicolumn{8}{|c|}{ Granex 33} \\
\hline Harvest & DAT $^{y}$ & & & & & & \\
\hline 1 & 94 & 2.7 & 5.1 & 6.0 & 4.5 & 8.1 & 9.7 \\
\hline 2 & 104 & 2.3 & 4.2 & 5.1 & 3.0 & 5.2 & 6.4 \\
\hline 3 & 115 & 1.8 & 3.4 & 4.1 & 2.3 & 4.2 & 5.1 \\
\hline 4 & 124 & 1.2 & 2.8 & 3.6 & 1.4 & 3.3 & 4.0 \\
\hline 5 & 132 & 1.6 & 3.4 & 4.8 & 2.0 & 3.6 & 4.8 \\
\hline Signifi & & $* *$ & $* *$ & $* *$ & $* *$ & $* *$ & $* *$ \\
\hline \multicolumn{8}{|c|}{ Initial storage temperature $\left({ }^{\circ} \mathrm{C}\right)$} \\
\hline 1 & & 1.8 & 3.8 & 4.8 & 2.4 & 4.9 & 6.1 \\
\hline 10 & & 2.1 & 3.7 & 4.6 & 2.9 & 4.9 & 5.9 \\
\hline Signifi & & $* *$ & NS & NS & $*$ & NS & NS \\
\hline \multicolumn{8}{|c|}{ Harvest $\times$ temperature } \\
\hline Signifi & & NS & NS & NS & NS & NS & NS \\
\hline
\end{tabular}

$10^{\circ} \mathrm{C}$ (Table 4$)$. They continued to lose weight during subsequent storage at $20^{\circ} \mathrm{C}$ (weeks 3 and 4 of storage), although at lower rates. 'Texas Grano 1015Y' bulbs from both locations that were initially stored at $1{ }^{\circ} \mathrm{C}$ lost more weight after 4 weeks of storage than did those initially stored $10^{\circ} \mathrm{C}$. There was less surface desiccation during the initial 2 weeks storage at $1{ }^{\circ} \mathrm{C}$. Bulbs from $\mathrm{H} 2$ to $\mathrm{H} 5$ generally lost less than did those from $\mathrm{H} 1$.

Delayed harvest $(\mathrm{H} 4, \mathrm{H} 5)$ resulted in significant increases in total yield and the proportion of large ( $>7.6 \mathrm{~cm}$ diameter) bulbs, weight, and decreases in the respiration rate, sprouting, and weight loss, all consistent with more mature bulbs. However, for onions grown under humid, subtropical conditions, storage decay increased with later harvests. Considering the above quality parameters, recommended harvest times for 'Granex 33' and 'Texas Grano 1015' are 115 and 132 DAT, respectively (H3). At this maturity $\approx 20 \%$ and $5 \%$ of the tops had fallen for these respective cultivars. Nondried bulbs harvested at this maturity could be stored for 2 weeks at $1{ }^{\circ} \mathrm{C}$ and $80 \% \mathrm{RH}$ plus 2 weeks at $20{ }^{\circ} \mathrm{C}$, allowing sufficient time for shipment to distant markets and retailing. Storage of bulbs from $\mathrm{H} 3$ at $10{ }^{\circ} \mathrm{C}$ and $80 \% \mathrm{RH}$ resulted in unacceptable rates of decay after an additional 2 weeks storage at $20^{\circ} \mathrm{C}$.

\section{Literature Cited}

Barton, K. 1992. Borrowed technology means yearround availability for sweet onions. The Grower. March. p. 34, 35.

Brewster, J.L. 1977a. The physiology of the onion. Part one. Hort. Abstr. 47:17-23.

Brewster, J.L. 1977b. The physiology of the onion. Part two. Hort. Abstr. 47:103-112.

Gull, D.D., D. Cartagena, and E.C. French. 1980. Análisis de calidad de tomate para lograr um mejor producto. Inst. Boliviano Tecnología Agropecuaria/Proyecto Desarrollo Chapare/ Univ. of Florida, Cochabamba, Bolivia.

Hardenburg, R.E., A.E. Watada, and C.Y. Wang. 1986. The commercial storage of fruits, vegetables, and florist and nursery stocks. Agr. Handbook No. 66, U.S. Dept. Agr./Agr. Res. Serv. Washington, D.C.

Hayslip, N.C., D.D. Gull, V.L. Guzman, J.R. Shumaker, and R.M. Sonoda. 1987. Bulb onion production in Florida. Florida Agr. Expt. Sta. Bul. 238.

Hoyle, B.J. 1948. Onion curing-A comparison of storage losses from artificial, field, and noncured onions. Proc. Amer. Soc. Hort. Sci. 52:407-414.

Isenberg, F.M.R. 1979. Controlled atmosphere storage of vegetables. Hort. Rev. 1:337-394.

Kopsell, D.E. and W.M. Randle. 1997. Onion cultivars differ in pungency and bulb quality changes during storage. HortScience 32:12601263.

Nilsson, T. 1980. The influence of the time of harvest on the chemical composition of onions.
Swedish J. Agr. Res. 10:77- 88.

Richwine, P.A. 1990. Effect of fall planting date on bulb yield of 'Sweet Winter' onion in the rolling plains of Texas. HortScience 25:981.

Rickard, P.C. and R. Wickens. 1977. The effects of time of harvesting of spring sown dry bulb onions on their yield, keeping quality, and skin quality. Expt. Hort. 29:45-51.

Smittle, D.A. Undated. The Vidalia onion: Past, present and future. Univ. of Georgia Coastal Plain Expt. Sta., Tifton.

Smittle, D.A. and B.A. Maw. 1988. Effects of maturity and harvest on storage and quality of onions. HortScience 23:141-143.

Snowden, A.L. 1992. Color atlas of post-harvest diseases and disorders of fruits and vegetables. Vol. 2. Vegetables. CRC Press, Boca Raton, Fla.

Stoffella, P.J. and R.M. Sonoda. 1982. Reduction of onion yield by chlorothalonil. HortScience 17:628-629.

Toledo, J., M. Sherman, and D.J. Huber. 1984. Some effects of cultivar, bulb size and preharvest treatments on storage characteristics of North Florida onions. Proc. Florida State Hort. Soc. 97:106-108.

Tucker, W.G. and R.L.K. Drew. 1982. Post-harvest studies on autumn-drilled bulb onions. The effect of harvest date, conditioning treatments and field drying on skin quality and on storage performance. J. Hort. Sci. 57:339-348.

Wall, M.M. and J.N. Corgan. 1994. Postharvest losses from delayed harvest and during common storage of short-day onions. HortScience 29:802-804. 